\title{
Deep "Aggressive" Angiomyxoma
}

National Cancer Institute

\section{Source}

National Cancer Institute. Deep "Aggressive" Angiomyxoma. NCI Thesaurus. Code C6936.

A locally infiltrating, non-metastasizing angiomyxoma arising from the pelviperineal region. It may recur following resection 